\title{
Communication
}

[Comunicação]

\section{Doppler and Elastography as complementary diagnostic methods for mammary neoplasms in female cats}

\author{
[Doppler e Elastografia como métodos diagnósticos complementares de \\ neoplasias mamárias em felinos]
}

\author{
M.A.R. Feliciano, M.C. Maronezi, M.B.S. Brito, A.P.R. Simões, G.S. Maciel, T.L.L. Castanheira, \\ E. Garrido, R.R. Uscategui, N.G. Miceli, W.R.R. Vicente
}

Faculdade de Ciências Agrárias e Veterinárias - UNESP-Jaboticabal, SP

Feline mammary neoplasm is the third most common neoplasm in domestic cats with most of these malignancies requiring early detection and aggressive therapy. For early diagnosis, invasive complementary methods are used; they include fine-needle aspiration, scraping of the ulcerated lesions, excisional biopsy and histopathology findings after mastectomy (Giménez et al., 2010). The use of conventional and Doppler ultrasonography has been described for the differentiation of breast masses (Feliciano et al., 2012), however, there are no reports of the use these techincs in the evaluation of mammary tumors in cats.

Elastography was first developed in the early nineties to study the hardness of tissues and has been used for identifying and differentiating between mammary tumors, diagnosing prostate tumors, monitoring focal fibrotic lesions and studying the structural properties of kidneys (Srinivasan et al., 2004). Qualitative ARFI elastography is an imaging method that can be used to evaluate the tissue stiffness, facilitating the diagnosis of breast lesions in humans. The more deformable tissues are likely to be benign, and the more malignant tissues are rigid (Tavassoli and Devilee, 2003). In veterinary, Feliciano et al. (2015) reported that elastography can be used to differentiate canine mammary tumors.

In this communication, we describe the use of conventional ultrasonography, Doppler and elastographic technique to assess mammary neoplasms in female cats. In the veterinary field, there are no previous reports on the use of this technique to evaluate mammary tumors in cats.

Two spayed female cats of undefined breeds, one that was 10 years old (case 1) and one that was 15 years old (case 2), presented nodules of the mammary glands for years. The cats underwent anamnesis, general and specific physical examinations (localisation, size, presence of adherence, regularity of the surface tumour and presence of ulceration), regional lymph node palpation, radiographic surveys and abdominal ultrasound.

The owners reported a history of contraceptive use during the oestrus of the animals. During the physical exam, no obvious health-compromising abnormalities were observed. Upon specific examination of the mammary glands, the following was observed: case 1) one nodule located in the right caudal abdominal breast (M4D), measuring $5.0 \mathrm{x} 3.0 \mathrm{~cm}$, with no adherence or ulceration and a regular surface; case 2) two nodules: one located in the right caudal thoracic breast (M2D), measuring $8.0 \times 5.9 \mathrm{~cm}$, and one in the right inguinal breast (M5D) measuring $3.1 \times 5.0 \mathrm{~cm}$, both of which showed no adherence or ulceration and a regular surface. Thoracic radiography and abdominal ultrasound were performed to rule out the presence of metastases.

The conventional ultrasound, Doppler and acoustic radiation force impulse (ARFI)

Recebido em 5 de fevereiro de 2015

Aceito em 1 de junho de 2015

E-mail: marcusfeliciano@yahoo.com.br 
elastography of the breast nodules were performed to evaluate the applicability of these techniques to determine the differentiation (benign or malignant) of the mammary tumors.

A single evaluator, who is experienced in ultrasonography examinations, performed the ultrasonography. Conventional ultrasound and Doppler were performed with a $9.0 \mathrm{MHz}$ linear transducer using ACUSON S2000/SIEMENS ultrasound equipment (Siemens, Munich, Germany). By ultrasound, the echotexture and echogenicity of the parenchyma and margin regularity of the mammary masses were scanned. Doppler enabled the visualisation of the presence and type of blood flow (arterial, venous or turbulent) in the mammary tumors and was used to assess the maximum velocity, minimum velocity and resistance index of the neoplasms (Feliciano et al., 2012).

In B-mode, the masses presented mixed echogenicity, heterogeneous echotexture and were not invasive. The results obtained through these exams for each case are presented in Table 1.

Table 1. Doppler findings of the mammary neoplasms in the two feline cases

\begin{tabular}{lccc}
\hline & Case 1 & Case 2 & Case 2 \\
\cline { 2 - 4 } \multicolumn{1}{c}{ Findings } & M4D & M2D & M5D \\
\hline - Vascularisation & arterial & arterial & arterial \\
- Maximum velocity $(\mathrm{cm} / \mathrm{s})$ & 23.1 & 47.4 & 24.5 \\
- Minimum velocity $(\mathrm{cm} / \mathrm{s})$ & 8.5 & 16.1 & 6.1 \\
- Resistive index & 0.63 & 0.66 & 0.75 \\
\hline
\end{tabular}

"mixed with liquid component; ${ }^{* *}$ mixed with liquid and solid component

M4D: right caudal abdominal mammary nodule; M2D: right caudal thoracic mammary nodule; M5D: right inguinal mammary nodule.

ACUSON S2000/SIEMENS (Munich, Germany) ultrasound equipment was used for the elastography with software for qualitative and quantification evaluation using the ARFI method (Virtual Touch Tissue Quantification) and a 9.0 $\mathrm{MHz}$ linear transducer. After conventional ultrasound, the qualitative ARFI technique was used, resulting in grayscale images of the breast tissue. The images were evaluated according to the presence of deformities and white areas (which show that the tissue is more elastic - less $\mathrm{rigid} / \mathrm{soft} / \mathrm{deformable}$ ) and dark regions (which show that the tissue is more rigid/hard/nondeformable) (Figure 1I). For the ARFI quantitative evaluation, after delimiting the mammary tumour, the $\mathrm{B}$ mode function for obtaining the shear velocity was used, and a calliper was positioned in the tumour parenchyma (Feliciano et al. 2014). Six measurements of each nodule were performed, and the mean shear velocity and standard deviations were determined (Figure 1II).

The qualitative and quantitative elastography of the mammary masses was performed without difficulties or limitations. The data obtained through these exams for each case are presented in Table 2
The animals did not present with any physical, radiographic or sonographic alterations (areas resembling metastasis) that would contraindicate surgical treatment; as a result, they were considered eligible for mastectomy. The indicated treatment was total mastectomy and chemotherapy if necessary. The nodule samples collected during mastectomy were sent for histopathological evaluation, and the tumors were classified according to the literature (Misdrop et al. 1999). The results of the histopathological evaluation were as follows: case 1 , tubular carcinoma; and case 2 , cribriform mammary carcinoma.

In veterinary settings, the routine use of ultrasound for the assessment of mammary neoplasms in small animals has not been widely adopted, and there are few studies correlating the gross and microscopic findings with the results of ultrasound imaging (Feliciano et al., 2012). There are no studies in felines that describe the use of conventional ultrasonography in the evaluation of mammary neoplasms of female cats; in addition, there are no studies on the use of ARFI elastography and Doppler for this evaluation. 

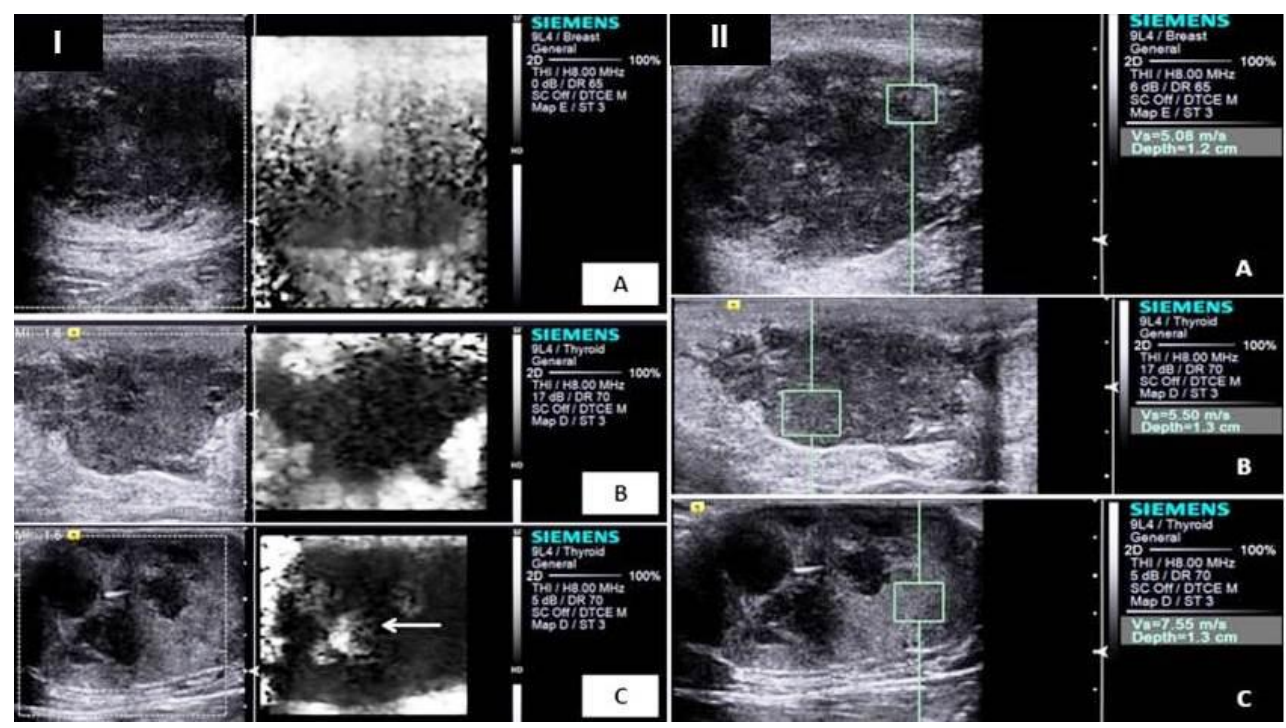

Figure 1. I) Image of the qualitative ARFI (acoustic radiation force impulse) elastography showing the characteristics of the stiffness in mammary tumors of the case reports. In nodule A (tubular carcinoma) and B (cribriform mammary carcinoma): homogeneous hard (black) and non deformable image; in nodule $\mathrm{C}$ (cribriform mammary carcinoma): heterogeneous hard image with a soft non deformable area (white) (arrow); II) Image of the quantitative ARFI (acoustic radiation force impulse) elastography in mammary tumors of the case reports. Note in A (tubular carcinoma), B and C (cribriform mammary carcinoma) the presence of the calipter within the neoplasm's parenchymal in nodules in the felines for mensurement of shear velocity.

Table 2. Qualitative and quantitative acoustic radiation force impulse (ARFI) elastography findings of the mammary neoplasms in the two feline cases

\begin{tabular}{|c|c|c|c|}
\hline & Case 1 & Case 2 & Case 2 \\
\hline Findings & M4D & M2D & M5D \\
\hline Qualitative: & & & \\
\hline - Grayscale & $\begin{array}{l}\text { homogenous } \\
\text { hard }\end{array}$ & $\begin{array}{l}\text { homogenous } \\
\text { hard }\end{array}$ & $\begin{array}{l}\text { heterogeneous } \\
\text { hard with soft areas }\end{array}$ \\
\hline - Deformable & no & no & no \\
\hline $\begin{array}{l}\text { Quantitative: } \\
\text { - Shear velocity }(\mathrm{m} / \mathrm{s})^{*}\end{array}$ & $4.07 \pm 0.68$ & $4.54 \pm 1.03$ & $6.85 \pm 0.6$ \\
\hline
\end{tabular}

In women, some conventional ultrasound findings may aid in the establishment of the tumour type; malignancy is suspected based on heterogeneity of the tumour tissue, irregular surface contours, the presence of unclear margins, posterior acoustic attenuation, skin thickening (hyperechogenicity) and the presence of calcifications (Lucena 2006). Among the sonographic findings, only heterogeneity of tumour tissue was observed in the mammary nodules of the cats based on the visualisation of the echotexture and the heterogeneous echogenicity of the parenchyma.
In bitches, the Doppler ultrasound is useful for the differentiation between malignant and benign mammary neoplasms using vascular indices (Lucena 2006). Specifically, the maximum velocity found in mammary tumors can indicate tissue malignancy $(>20.00 \mathrm{~cm} / \mathrm{s})$, as observed in humans (Dock et al., 1991) and canines (Feliciano et al., 2012), which corroborates the findings observed in the mammary nodules of the female cats in this report. According to the literature, the changes in tumour blood flow, the presence of turbulent flow, high-impedance pulsatile signal (penetration), increased 
maximum velocity and venous flow are also indicative of malignant lesions.

The qualitative assessment of ARFI elastography assists in the conventional ultrasonographic evaluation of mammary neoplasms and increases the sensitivity of the detection of tissue heterogeneity (Yoon et al., 2013) and tumour deformity: based on elastography, benign mammary lesions in women are deformable, and malignant lesions are rigid or non-deformable (Comstock et al., 2011) which are similar to the findings observed in the malignant mammary nodules of the cats in this report.

For quantitative study, ARFI facilitated the verification of high values of shear velocities of malignant mammary neoplasms (case 1: $4.07 \pm 0.68 \mathrm{~m} / \mathrm{s}$; case $2 \mathrm{M} 2 \mathrm{D}: 4.54 \pm 1.03$; and M5D: $6.85 \pm 0.6 \mathrm{~m} / \mathrm{s}$ ); these values are similar to those reported in human studies (malignant:
$5.62 \pm 3.26 \mathrm{~m} / \mathrm{s}$ and benign: $2.68 \pm 1.20 \mathrm{~m} / \mathrm{s}$ ) (Zhou et al., 2013) and canines (malignant: $3.33 \mathrm{~m} / \mathrm{s} \mathrm{m} / \mathrm{s}$ and benign: $1.28 \mathrm{~m} / \mathrm{s} \mathrm{m} / \mathrm{s}$ ) (Feliciano et al., 2014). The increased stiffness of the malignant lesions in the present case report as well as studies in humans (Zhou et al., 2013) may be explained by the presence of a stromal reaction induced by mammary carcinoma associated with increased amounts of collagen components in tumour tissues.

It is expected that the use of new ultrasound techniques for assessing mammary neoplasms in cats can promote the early, safe and non-invasive diagnosis of these lesions, as observed in the present report, favouring an appropriate and rapid management of the patient.

Keywords: feline, mammary ultrasonography, elastography

\section{RESUMO}

Objetivou-se descrever a utilização das técnicas Doppler e elastografia ARFI (acoustic radiation force impulse) na avaliação de neoplasias mamárias de gatas, métodos ainda não utilizados para tal estudo em fêmeas felinas. Após a avaliação física e específica das neoplasias mamárias de duas gatas, foram realizadas as avaliações ultrassonográfica modo-B (ecogenicidade, ecotextura e margeamento), Doppler colorido (característica do fluxo sanguíneo) e espectral (velocidade sistólica/VS; diastólica/VD; e índice de resistência/IR) e a eslatografia ARFI qualitativa (escala de cores) e quantitativa (velocidade de cisalhamento) dos nódulos mamários, avaliando a aplicabilidade destas técnicas para determinar a malignidade dos tumores mamários. Após mastectomia e histopatologia foram diagnosticados: caso 1: carcinoma tubular; e caso 2: carcinoma mamário cribiforme. As características do modo-B foram similares para ambos os casos (heterogeneidade e margens regulares e não invasivas). Ao Doppler verificou-se presença de neovascularização e valores considerados elevados para os índices vasculares (quando comparado com tecidos benignos de outras espécies, como por exemplo caninos) (caso 1 - VS: 23,1 cm/s, VD: 8,5cm/s e IR: 0,63; caso 2 -VS: 47,4 e 24,5cm/s; VD: 16,1 e 6,1 cm/s e IR: 0,66 e 0,75); assim como os valores da velocidade de cisalhamento dos tecidos (caso 1: 4,07 m/s; caso 2: 4,54 e 6,85 $\mathrm{m} / \mathrm{s}$ ) na elastografia quantitativa; sendo que na avaliação qualitativa observou-se predominante rigidez $e$ não deformidade tecidual, características que podem indicar a malignidade tecidual. Conclui-se que estas técnicas podem auxiliar no estudo de neoplasias mamárias em felinos, sugerindo a implementação destas técnicas de imagem para estudos de tumores mamários em felinos.

Palavras-chave: felinos, ultrassonografia mamária, elastografia

\section{ACKWNOLEGMENTS}

The authors are thankfull to FAPESP for the grant and financial support for post doctoral research (2010/16913-7 and 2011/06011-9).

\section{REFERENCES}

COMSTOCK C. Ultrasound elastography of breast lesions. Ultrasound Clin., v.6, p.407-415, 2011.

DOCK, W.; GRABENWOGER, F.; METZ, V. et al. Tumor vascularization: assessment with Duplex Sonography. Radiology, v.181, p.241-244, 1991. 
FELICIANO, M.A.R.; SILVA, M.A.M.; VICENTE, W.R.R. Conventional and Doppler ultrasound for the differentiation of benign and malignant canine mammary tumors. J. Small Anim. Pract., v.53, p.332337, 2012.

FELICIANO, M.A.R.; MARONEZI, M.C.; PAVAN, L. et al. ARFI elastography as complementary diagnostic method of mammary neoplasm in female dogs - preliminary results. J. Small Anim. Pract., v.55, p.504-508, 2014.

GIMÉNEZ, F.; HECHT, S.; CRAIG, A.M. Early detection, aggressive therapy optimizing the management of feline mammary masses. J. Feline Med. Surg., v.12, p.214-224, 2010.

LUCENA, C.E.M. Indice de avaliação ecográfica nos estudos dos nódulos sólidos mamários: uma nova proposta de classificação. 2006.152f. Tese (Doutorado) - Faculdade de Medicina, Universidade Federal de Minas, Belo Horizonte, MG.
MISDROP, W.; ELSE, R.W.; HELLMÉN, E. et al. Histological classification of mammary tumors of the dog and the cat. In: INTERNATIONAL histological classification of tumors of domestic animals. 2.ed. Washington: Armed Forces Institute of Pathology/American Registry of Pathology/World Health Organization, 1999. v.7, p.1-59.

SRINIVASAN, S.; KROUSKOP, T.; OPHIR, J. A quantitative comparison of modulus images obtained using nanoindentation with strain elastograms. Ultrasound Med. Biol., v.30, p.899-914, 2004.

TAVASSOLI, F.A.; DEVILEE, P. Pathology and genetics: tumors of the breast and female genital organs. Lyon, France: IARC, 2003.

YOON, J.H.; KO, K.H.; JUNG, H.K. et al. Qualitative pattern classification of shear wave elastography forbreast masses: how it correlates to quantitative measurements. Eur. J. Radiol., v.82, p.2199-2204, 2013.

ZHOU J., ZHAN W., CHANG C. et al. Role of acoustic shear wave velocity measurement in characterization of breast lesions. J. Ultrasound Med., v.32, p.285-294, 2013. 